\title{
ASSOCIATION OF SINGLE NUCLEOTIDE POLYMORPHISM IN CHROMOSOME 11 WITH AUTISM SPECTRUM DISORDER
}

\author{
Daiga Bauze*,**, Linda Piekuse***, Laura Kevere*, Zane Kronberga*, Arnis Riževs*,

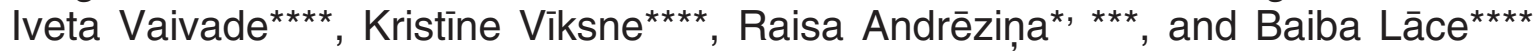 \\ * Children's University Hospital, Child Psychiatry Clinic, Juglas iela 20, Rĩga, LV-1079, LATVIA; \\ daiga.bauze@gmail.com \\ ** Children's University Hospital, Medical Genetics Clinic, Juglas iela 20, Rīga, LV-1079, LATVIA \\ *** Rīga Stradiṇš University, Dzirciema 16, Rīga, LV-1007, LATVIA \\ **** Latvian Biomedical Research and Study Centre, Rātsupītes iela 1, Rīga, LV-1067, LATVIA
}

Communicated by Isaak Rashal

\begin{abstract}
Several genetic loci in chromosomes 11 and 15 have recently been associated with non-syndromic autism spectrum disorder (ASD) in populations from North America and Europe. The aim of the present study was to investigate whether such an association exists in a Latvian population. Ninety-five patients with ASD in the age range 3-20 years (mean age 8 years, SD 3.18) participated in the study. The control group consisted of 161 healthy, non-related individuals without ASD randomly selected from the Latvian Genome Database. Four single nucleotide polymorphisms (SNPs) - rs11212733, SNP rs1394119, rs2421826, rs1454985 - were genotyped by the TaqMan method. Allele frequency differences between ASD patients and control subjects were compared for each SNP using a standard chi-square test with Bonferroni correction. The level of statistical significance was set at 0.05 for nominal association. Only the genetic marker rs11212733, localised on the long arm of chromosome 11 in locus 22.3, was found to be strongly associated with the ASD patient group ( $\chi^{2} 6.982$, Padjusted 0.033 , odds ratio 1.625). Our data demonstrating a significant relationship between the SNP rs11212733 and the development of $A S D$ in a Latvian population suggest that it is not a population-specific relationship. Thus, future studies focusing on the DDX10 gene and related genetic loci are needed.
\end{abstract}

Key words: autism spectrum disorder (ASD), single nucleotide polymorphisms (SNPS), rs11212733, DDX10.

\section{INTRODUCTION}

Autism spectrum disorders (ASD) are serious early childhood neurodevelopmental disorders with unknown etiology and a rapid annual increase in prevalence. ASD are a broad phenotype including less severe disorders (Anonymous, 1994; Bailly et al., 1996; Johnson et al., 2007). ASD are clinically characterised by impaired social and communication skills, hyperactivity and attention deficit, stereotypic movements and interests, stereotypic rituals, emotional disturbances, and varying degrees of expressive and receptive language development disorders (Bailly et al., 1996; Risch et al., 1999).

ASD is not a disease but rather a syndrome that is characterised by a multifactorial type of inheritance. In some cases, it is one of the symptoms of monogenic or chromosomal pathology, and can also be a symptom of inherited metabolic disorders. In early childhood, the latter can manifest primarily with autistic behaviour, speech development delay or re- gression, and mental retardation. This collection of symptoms should be classified as ASD (Gillberg et al., 2006). The International Classification of Diseases (ICD-10) distinguishes between autism and ASD, which are subdivided into syndromic autism and non-syndromic or idiopathic autism (Anonymous, 1992; Lintas and Persico, 2009).

Linkage and association studies have identified potential ASD candidate genes in different chromosomes - the most significant ones being 2q, 7q, 15q and the $\mathrm{X}$ chromosome (Muhle et al., 2004; Lintas and Persico, 2009). As several genetic loci have been implicated in ASD development, extensive studies have been conducted worldwide to detect potential candidate genes for ASD (Liu et al., 2008; Cho et al., 2011). Genome-wide linkage analyses of quantitative and categorical autism subphenotypes, carried out in North America and Europe, revealed association between ASD and locus 15.4-p15.3 in the short arm of chromosome 11 (Liu et al., 2008). Furthermore, cytogenetic abnormalities at 
locus 11-13 in the long arm of chromosome 15 have been reported to cause ASD. Population studies and case reports describe the duplication, deletions and inversions of this locus, as well as the phenotype of chromosome 15 in ASD patients (Muhle et al., 2004; Johnson et al., 2011).

The aim of this study was to investigate whether the association between reported ASD informative genetic markers in chromosomes 11q, 11p, and 15q and non-sindromic autism spectrum disorders exists in a Latvian population.

\section{MATERIALS AND METHODS}

Subjects. The Children's Psychiatry Clinic of the Children's University Hospital is one of four specialised centres in Latvia. Since 2006, 195 patients with possible ASD have attended for a consultation. The given patient group was primarily examined by a psychiatrist using ICD-10 diagnostic criteria, as well as standardised scales corresponding to each patient's age: The CHecklist for Autism in Toddlers (the CHAT) (assessment in the first 18 months); Autism Spectrum Quotient (autism spectrum questions for children aged 4-11 years); Cambridge University Behaviour and Personality questions for children up to the age of four years; Cambridge University social and communicative development questions; and Childhood Asperger Syndrome Test (CAST) (Anonymous, 1992; Baron-Cohen et al., 1992; Scott et al., 2002; Baron-Cohen et al., 2006; Williams et al., 2006). In order to specify the diagnosis of ASD in cases with positive test results, they were referred to a psychologist for the Autism Diagnostic Observation Schedule (ADOS) test, using the most appropriate model of the given test for each patient (Lord et al., 2002). Thus, on the basis of the test results, of the 195 patients, diagnoses of ASD were confirmed in 169 and were selected.

A clinical geneticist performed the genetic assessment of all patients. Seventy-four patients were excluded from the group as monogenic, chromosomal and metabolic pathologies, diagnosed using standard karyotype, long arm of chromosome 15 locus 11.13 (15q11.13) deletion/duplication and long arm of chromosome 22 locus 11.2 (22q11.2) deletion analyses.

Ninety-five patients with ASD in the age range 3-20 years (mean age 8 years, SD 3.18) agreed to participate in the study. The male to female ratio was 3.5:1. The patients, legal guardians or parents signed informed consent forms in accordance with the instructions issued by the Medical Ethics Committee of Rīga Stradiňš University.

The control group comprised 161 healthy, non-related individuals randomly selected from the Latvian Genome Database. A subject was excluded from the control group if there was information concerning possible mental illness. The male to female ratio was $1.7: 1$.

Analysed patients and control group individuals corresponded to the ethnic structure of the general Latvian population.
Methods. DNA was extracted from each patient's venous blood sample (collected at the Children's Psychiatry and Medical Genetics Clinics of the Children's University Hospital) using a standard phenol/chloroform extraction protocol (Sambrook et al., 1989).

Single Nucleotide Polymorphism (SNP) Selection. On the basis of the data of recent reports on the most significant SNPs involved in the development of ASD, four SNPs were selected for the genotyping assay: rs11212733 at the long arm of chromosome 11 in locus 22.3, SNP rs1394119 at the short arm of chromosome 11 in locus 15.4-15.3, rs2421826 at the short arm of chromosome 11 in locus 13 and rs1454985 at the long arm of chromosome 15 in locus 13.3-14 (Liu et al., 2008; Cho et al., 2011).

TaqMan Genotyping. SNPs were genotyped using TaqMan ${ }^{\circledR}$ probe-based chemistries (Applied Biosystems, Carlsbad, CA, USA) on an automatic sequence-detection instrument (Real-Time PCR System, Applied Biosystems). All reactions were carried out using standard conditions as recommended by the manufacturer.

Statistical analysis. Allele frequency differences between ASD patients and control subjects were compared for each SNP using a standard chi-square test with Bonferroni correction. Allelic odds ratios and $95 \%$ confidence intervals were estimated using a standard chi-square test, assuming a multiplicative model. The level of statistical significance was set at 0.05 for nominal association. Statistical analyses were conducted using PLINK 1.06 software (Purcell et al., 2007).

\section{RESULTS}

Four SNPs in the analysed genetic loci related to ASD were genotyped in 95 patients with ASD and 161 healthy, nonrelated controls. The average genotype call rate for these SNPs was $99.8 \%$.

The genotype distributions in the study groups were in Hardy-Weinberg equilibrium, except for rs1394119, which was excluded from further studies. The genomic control inflation factor $(\mathrm{kGC})$ was 1.008 for the entire data set. The results are shown in Table I.

Our results showed that the genetic marker rs11212733, localised on the long arm of chromosome 11 in locus 22.3, was found to be associated with ASD $\left(\chi^{2}-6.982, P_{\text {adjusted }}\right.$ -0.033 , odds ratio -1.625$)$. The genetic markers rs2421826, localised on the short arm of chromosome 11 in locus 3 and rs1454985, localised on the long arm of chromosome 15 in locus $13.3-14$ did not have an association with $\operatorname{ASD}\left(\chi^{2}-0.554, P_{\text {adjusted }}-1.0\right.$, odds ratio $-1.154 ; \chi^{2}$ $-1.118, P_{\text {adjusted }}-1.0$, odds ratio -1.217 , accordingly).

\section{DISCUSSION}

Although we did not detect an association of rs2421826 or rs1454985 with ASD (perhaps due to the small number and 
RESULTS OF CASE-CONTROL ASSOCIATION STUDY

\begin{tabular}{c|c|c|c|c|c|c|c|c}
\hline Chr & SNP & MAF cases & MAF controls & $\chi^{2}$ & $P$ value & $P_{\text {adjusted }}$ & Odds ratio & $95 \%$ CI \\
\hline $11 \mathrm{q} 22.3$ & rs11212733 & 0.552 & 0.432 & 6.982 & 0.008 & 0.033 \\
$11 \mathrm{p} 13$ & rs2421826 & 0.352 & 0.432 & 0.554 & 0.456 & 1.625 & 1.0 \\
$15 \mathrm{q} 13.3-\mathrm{q} 14$ & rs1454985 & 0.447 & 0.399 & 1.118 & 0.291 & 1.154 & 1.0
\end{tabular}

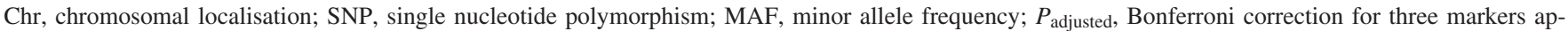
plied; CI, confidence interval

more homogeneous nature of our non-syndromic ASD cases), the SNP rs11212733, in chromosome 11q22.3 and located to the 5' region of the exophilin 5 (EXPH5) gene and 3' of the DEAD (Asp-Glu-Ala-Asp) box polypeptide 10 (DDX10) gene, was found to be strongly associated with our ASD patient group $\left(\chi^{2}-6.982, P_{\text {adjusted }}-0.033\right.$, odds ratio $-1.625,95 \% \mathrm{CI}-1.13-2.31)$. This genetic marker has recently been reported to be significant in a Korean population (Cho et al., 2011). As our Latvian ASD patients belong to a North-Eastern European population, which is distinct from a Korean population (Asian), our data suggest that the genetic marker at locus 11q22.3 is linked to a genetic locus that plays a prominent role in the development of ASD and is not population-specific.

EXPH5 is a protein-coding gene localised at the long arm of chromosome 11 in locus 22.3. A known function of this gene is related to Rab27, which governs the regulated exocytosis in non-neuronal cells, such as lytic granule secretion in cytotoxic T cells, production of insulin in pancreatic $\beta$-cells, as well as the release of histamine-containing granules in mast cells. Rab27 is also responsible for melanosome transport along the actin cytoskeleton in melanocytes (Kondo et al., 2006). As EXPH5 does not appear to be involved in neurological processes, it is probably not of notable significance in ASD.

The DDX10 gene at the long arm of chromosome 11 in locus 22-23 encodes an RNA helicase, involved in RNA duplex unwinding and ribosome assembly. Although it is not known which RNA molecules are unfolded by this helicase, impaired function of DDX10 would be expected to cause regulatory problems at the RNA level (Savitsky et al., 1996). Thus, $D D X 10$ is a more promising candidate gene for further research concerning the development of ASD.

Our data demonstrating a significant relationship between the SNP rs11212733 and the development of ASD in a Latvian population suggest that it is not a population-specific relationship. Thus, future studies focusing on the DDX10 gene and related genetic loci are needed.

\section{ACKNOWLEDGMENTS}

This study was supported by the European Social Foundation (ESF), Project No. 2009/0147/1DP/1.1.2.1.2/09/IPIA/ VIAA/009. We are grateful to all the parents and children for their participation in this study.

\section{REFERENCES}

Anonymous (1992). The ICD-10 classification of mental and behavioural disorders; clinical description and diagnostic guidelines. World Health Organization. Geneva, WHO.

Anonymous (1994). Diagnosis and Statistical Manual of Mental Disorders, 4th Edition $(D S M-I V)$. American Psychiatric Association. Washington DC: American Psychiatric Publishing.

Bailley, A., Phillips, W., Rutter, M. (1996). Autism: Towards an integration of clinical, genetic, neuropsychological and neurobiological perspectives. J. Child Psychol. Psychiatry, 37, 89-126.

Baron-Cohen, S., Allen, J., Gillberg, C. (1992). Can autism be detected at 18 month? The needle, the haystack, and the CHAT. Br. J. Psychiatry, 161, 839-843.

Baron-Cohen, S., Hoekstra, A. R., Knickmeyer, R., Wheelwright, S. (2006). The Autism Quotient (AQ) - adolescent version. J. Autism Devel. Disord., 36, 343-350.

Cho, S. C., Yoo, H. J., Park, M., Cho, I. H., Kim, B. N., Kim, J. W., Shin, M. S., Park, T. W., Son, J. W., Chung, U. S., Kim, H. W., Yang, Y. H., Kang, J. O., Yang, S. Y., Kim, S. A. (2011). Genome-wide association scan of Korean autism spectrum disorders with language delay: A preliminary study. Psychiatry Investig., 8, 61-66.

Gillberg, C. (2006). Autism spectrum disorders. In: Gillberg, C., Harrington, R., Steinhausen, H. C. (eds.). A Clinician's Handbook of Child and Adolescent Psychiatry (pp. 447-489). UK Cambridge University Press.

Johnson, C. P., Myuer, S. M. (2007). Identification and evaluation of children with autism spectrum sisorders. Pediatrics, 120, 1183-1215.

Johnson, H. M., Gaitanis, J., Morrow, E. M. (2011). Genetics in autism diagnosis: Adding molecular subtypes to neurobehavioral diagnoses. Medical Health R. I., 94, 124-126.

Kondo, H., Shirakawa, R., Higashi, T., Kawato, M., Fukuda, M., Kita, T. , Horiuchi, H. (2006). Constitutive GDP/GTP exchange and secretion-dependent GTP hydrolysis activity for Rab27 in platelets. J. Biol. Chem., 29 (281), 28657-28665.

Lintas, C., Persico, A. M. (2009). Autistic phenotypes and genetic testing: State-of-the art for the clinical geneticist. J. Med. Genet., 46, 1-8.

Liu, X. Q., Paterson, A. D., Szatmari, P. (2008). Genome-wide linkage analyses of quantitative and categorical autism subphenotypes. J. Biol. Psychiatry, 647, 561-570.

Lord, C., Rutter, M., DiLavore, P. C., Risi, S. (2002). Autism Diagnostic Observation Scedule. Manual. Los Angeles: Western Psychological Services.

Muhle, R., Trentacoste, S. V., Rapin, I. (2004). The genetics of autism. Pediatrics, 113 (5), 472-486.

Purcell, S., Neale, B., Todd-Brown, K., Thomas, L., Ferreira, M. A., Bender, D., Maller, J., Sklar, J., de Bakker, P. I., Daly, M. J., Sham, P. C. (2007). PLINK: A tool set for whole-genome association and population-based linkage analyses. Eur. J. Hum. Genet., 81, 559-575.

Risch, N., Spiker, D., Lotspeich, L., Nourj, N., Hinds, D., Hallmayer, J., Kalaydjieva, L., McCague, P., Dimiceli, S., Pitts, T., Nguyen, L., Yang, J., Harper, C., Thorpe, D., Vermeer, S., Young, H., Hebert, J., Lin, A., Ferguson, J., Chiotti, C., Wiese-Slater, S., Rogers, T., Salmon, B., Nicholas, P., Petersen, P. B., Pingree, C., McMahon, W., Wong, D. L., CavalliSforza, L. L., Kraemer, H. C., Myers, R. M. (1999). A genomic screen of 
autism: Evidence for a multilocus etiology. Amer. J. Hum. Genet., 65 , 493-507.

Sambrook, J., Fritsch, E. F., Maniatis, T. (1989). Molecular Cloning: A Laboratory Manual. Cold Spring Harbor: Cold Spring Harbor Laboratory Press.

Savitsky, K., Ziv, Y., Bar-Shira, A., Gilad, S., Tagle, D. A., Smith, S., Uziel, T., Sfez, S., Nahmias, J., Sartiel, A., Eddy, R. L., Shows, T. B., Collins, F. S., Shiloh, Y., Rotman, G. (1996). A human gene (DDX10) encoding a pu- tative DEAD-box RNA helcase at 11q22-q23. Genomics, 15 (33), 199-206.

Scott, F. J., Baron-Cohen, S., Bolton, P., Brayne, C. (2002). The CAST (Childhood Asperger Syndrome Test): Preliminary development of a UK screen for mainstream primary-school age children. Autism, 6, 9-31.

Williams, J., Allison, C., Scott, F.., Ctott, C., Bolton, P., Baron-Cohen, S., Brayne, S. (2006). The Childhood Asperger Syndrome Test (CAST): Test-retest reliability. Autism, 10, 415-427.

Received 21 November 2012

\section{AUTISKĀ SPEKTRA TRAUCĒJUMU SAISTİBA AR 11. HROMOSOMAS G̣ENĒTISKO POLIMORFISMU}

Autiskā spektra traucējumi (AST) ir agrīns, komplekss psihiskās attīstības bojājums, kurš sākas un tiek diagnosticēts bērniem līdz trīs gadu vecumam. AST ir multifaktoriāla ǵenētiska slimība, kuras izcelsmē iesaistīti daudzi iespējamie kandidātgēni. Veikto gadījuma kontroles asociācijas pētījumu mērkis bija noskaidrot vai pastāv 11. un 15. hromosomu ġenētiskā polimorfisma saistība ar AST Latvijas populācijā. Balstoties uz literatūras datiem, tika izvēlēti četri potenciāli nozīmīgi SNP (rs11212733, rs1394119, rs2421826, rs1454985), kuri varētu būt iesaistīti AST attīstībā. Pētāmo grupu veidoja VSIA BKUS BS Gaiḷezers Bērnu psihiatrijas un Medicīniskās ǵenētikas klīnikas 95 pacienti ar autismu un AST, kuru vecāki vai aizbildṇi rakstiski piekrita bērna ğenētiskā materiāla tālākai izpētei. Pētījuma kontroles grupā iekḷāva nejaušināti atlasītas 161 potenciāli veselas, savstarpēji neradniecīgas personas no Valsts iedzīvotāju genoma datubāzes, kuriem anamnēzē nav datu par AST vai citiem psihiskiem traucējumiem ğimenē. Izvēlēto alēlu genotipēšana veikta Latvijas Biomedicīnas Pētîjumu un studiju centrā, izmantojot TaqMan reaktīvus. Statistiskā datu analīze veikta, izmantojot PLINK 1.06 programmatūru, salīdzinot AST un kontroles grupu. Datu statistiskai apstrādei izmantots standarta Hī kvadrāta $\left(\chi^{2}\right)$ tests ar Bonferoni korekciju. Pētījumā atklāta statistiski ticama SNP rs11212733 (lokalizēts 11. hromosomas garā plecā 22.3 lokusā) saistība ar AST attīstību Latvijas populācijā $\left(\chi^{2} \quad 6,982 ; P\right.$ koriǵēts 0,033 ; izredžu attiecība 1,625). Literatūrā aprakstītais polimorfisms ir saistīts ar autiskā spektra traucējumiem Dienvidkorejas pacientiem. Rs11212733 atrodas 11. hromosomas nekodējošā rajonā starp gēniem EXPH5 un DDX10, kuru nozīme autisma attīstîbā vēl nav pierādīta. Nepieciešami turpmāki pētījumi. 